\title{
Temperature and Substrate Effects on the Structural, Morphological, and Optical Properties of Iron Oxide Thin Films Prepared by Spray Pyrolysis Technique
}

\author{
Zannatul Ferdous $^{1}$, Md. Samir Ullah ${ }^{2}$ and Sabina Hussain ${ }^{1}$ * \\ ${ }^{1}$ Department of Physics, University of Dhaka, Dhaka-1000, Bangladesh \\ ${ }^{2}$ Department of Physics, Bangladesh University of Engineering and Technology, Dhaka-1000, Bangladesh
}

(Received : 8 September 2019 ; Accepted : 7 January 2020 )

\begin{abstract}
Glass and Fluorine doped Tin Oxide (FTO) coated conducting glass substrates have been chosen for the deposition of Iron Oxide thin films prepared by Spray Pyrolysis Technique. The films were grown at different substrate temperatures $\left(350^{\circ} \mathrm{C}, 400^{\circ} \mathrm{C}\right.$, and $\left.450^{\circ} \mathrm{C}\right)$ and they were annealed at $300^{\circ} \mathrm{C}$ for $1 \mathrm{hr}$. Structural, morphological, optical characterizations of the films have been studied by X-ray diffraction, atomic force micrograph, UV spectroscopy methods. From the XRD studies, films on glass substrates are found to be amorphous in nature with $\alpha$-hematite phase and crystalline on FTO coated conducting glass substrates. AFM analysis indicates that the films grown on glass substrates are rougher than the films on FTO coated conducting glass substrates. It reveals that the FTO coated conducting glass substrates can be a better choice as a substrate. The transmis sion spectra have been measured in the wavelength range 200-1200 nm. The transmittance of the films both on glass and FTO coated conducting glass substrates has been observed to be about 40$80 \%$ in the wavelength range $(500-1100) \mathrm{nm}$. The optical band gap energy values have been found to be in the range 2.10-2.37 eV.
\end{abstract}

Keywords: Spray Pyrolysis, Iron Oxide $\left(\mathrm{Fe}_{2} \mathrm{O}_{3}\right)$, Transmittance, Band gap.

\section{Introduction}

For the past decades various types of films such as composite films, non metallic inorganic films, transition metal oxide films etc. have been studied extensively in the field of materials science. Transition metal oxides (TMO) have emerged to be interesting classes of solids because of their distinguishable electronic properties due to the unique nature of outer d-electrons ${ }^{1}, 7$.TMO materials include wide band gap insulators, semiconductors, metals, or superconductors . They can go through semiconductor to metal transition. Some examples of TMO materials are Titanium dioxide $\left(\mathrm{TiO}_{2}\right)$, Nickel Oxide( $\left.\mathrm{NiO}\right)$, Manganese oxide $\left(\mathrm{MnO}_{2}\right)$, Iron oxide $\left(\mathrm{Fe}_{2} \mathrm{O}_{3}\right)$ etc. Materials defects like vacancies, dislocations, stacking faults and grain boundaries are responsible to have remarkable optical and magnetic properties of these materials. Because of their unique properties TMO materials find applications from energy and information technologies to ion conductors through photovoltaics, from thermoelectrics to dielectrics, multiferroics and capacitors. Their uses as electrodes in electrochemical processes, functional components in catalytic processesare also noteworthy applications ${ }^{2,8}$. $\mathrm{MnO}_{2}$ is one of the best candidates on account of its electrochemical behaviour, low cost, high theoretical specific capacitance and environmental compatibility ${ }^{3-5}$. On the other hand, silver oxide thin films have been proved to be very effective material for dealing with optical near-field and surface plasmons ${ }^{4,6}$. $\mathrm{NiO} / \mathrm{Ni}$ thin films have been used as selective solar absorbers ${ }^{5,7} \cdot \mathrm{SnO}_{2}$ has been widely characterized and explored in a variety of applications such as solid state gas sensors, solar cells, transparent electrodes and other optoelectronic devices ${ }^{6,8}$.
In recent times, large number of improvements has been made using different materials techniques to fabricate solar cells in order to overcome the first generation solar cells based on silicon. CIGS (Copper Indium Gallium Selenide) is one of the thin film based solar cells whose efficiency has been recorded $22.9 \%$ which is an improvement over other cell materials. In CIGS, there is a buffer layer which is made of materials which have higher transmittance. Generally transition metal oxide film is used to develop that layer of CIGS. Films can be deposited by using different techniques such as-chemical bath deposition, chemical vapor deposition, electrodeposition, molecular beam epitaxy, sol-gel process, spin coating, dip coating, spray pyrolysis etc. Such a wide variety of techniques is very useful of tailoring and engineering of the layers in order to make device performance more efficient ${ }^{9}$.

Over years, attention has been paid on iron oxide materials and its thin films, one of the TMO materials. Alaa A.Akl suggested that by varying substrate temperature and deposition time, non crystalline and crystalline iron oxide thin films on glass can be fabricated ${ }^{10}$. Salam Amir Yousif also studied the temperature effect on iron oxide thin films made by spray pyrolysis method ${ }^{11}$. Chemical Bath Deposition Technique has been used by Batin, et.al. to make iron oxide thin films on glass substrate and their work was focused on the optical properties of the films ${ }^{12}$. Most of the works done so far, iron oxide thin films were grown on glass substrates whereas Desai, et.al. fabricated iron oxide films on ITO coated glass substrates and structural, morphological, and optical studies were performed ${ }^{13}$. GarciaLobato, et. al. obtained the amorphous and polycrystalline iron oxide thin films on glass substrates with the variation of temperature $^{14}$. 
Based on the earlier reports, an attempt has been made in our work to prepare iron oxide thin films on glass and FTO coated conducting glass substrates by spray pyrolysis technique. The substrate temperatures were varied keeping the deposition time unchanged and the films were annealed. Our observations were mainly focused on the effects of temperature and substrate type namely glass and Fluorine doped Tin Oxide (FTO) coated conducting glass substrates on the films. Structural, morphological, optical properties of the as-deposited and annealed films have been studied by the X-ray diffraction (XRD), atomic force microscopy (AFM), UV spectroscopy methods.

\section{Experimental Details}

Iron oxide films were deposited on glass and FTO coated conducting glass substrates using sprayingpyrolysis technique(SPT). The precurser solution of $0.1 \mathrm{M}$ concentration was prepared by mixing $1.6221 \mathrm{~g}$ of anhydrous ferric chloride $\left(\mathrm{FeCl}_{3}\right)$ in $100 \mathrm{~mL}$ distilled water.The colour of the ferric chloride solution was yelloworange which was kept in the beaker at $70^{\circ} \mathrm{C}$ for 10 min.The substrates were preheated at different temperatures $350^{\circ} \mathrm{C}, 400^{\circ} \mathrm{C}$, and $450^{\circ} \mathrm{C}$. In this process spray rate and deposition time were kept constant so that the film thickness remains the same.The deposition time was maintained at 12 minutes for all the cases.The spray rate was almost kept constant at $0.08 \mathrm{~mL} / \mathrm{min}$. The pressure was maintained at 0.5 bar when the solution was reaching the air blast.The solution formed spray and was sprayed over the preheated substrate. The films thus formed were brownishred in colour. All the films were annealed at $300^{\circ} \mathrm{C}$ for $1 \mathrm{hr}$. The thermal decomposition reaction which occurs in this spraying technique is :

\section{$2 \mathrm{FeCl}_{3}+3 \mathrm{H}_{2} \mathrm{O} \rightarrow \mathrm{Fe}_{2} \mathrm{O}_{3}+6 \mathrm{HCl} \uparrow$}

The characterizations of the film materials have been made using the following instruments: structural characterization of $\mathrm{Fe}_{2} \mathrm{O}_{3}$ films was made using RIGAKU Ultima IV X-ray diffractometer with $\mathrm{CuK}_{\alpha}$ radiation. A range of $2 \theta\left(10^{\circ}\right.$ to $70^{\circ}$ ) was scanned to cover all the diffraction peaks of the iron oxide phase.The surface morphological studies were carried out using Atomic Force Microscope(AGILENTN9410A-5500).Optical properties were investigated using a spectrophotometer (Model-OPTIZEN POP) in the wavelength range (200-1200nm).

\section{Results and Discussion}

XRD studies:

The XRD patterns of $\mathrm{Fe}_{2} \mathrm{O}_{3}$ thin film deposited by SPT on glass and FTO coated conducting glass substrates at different substrate temperatures $\left(350^{\circ} \mathrm{C}, 400^{\circ} \mathrm{C}\right.$, and 450C)) are shown in Fig. 1. Table 1 shows the peak list of $\mathrm{Fe}_{2} \mathrm{O}_{3}$ films on glass and FTO coated conducting glass substrates.
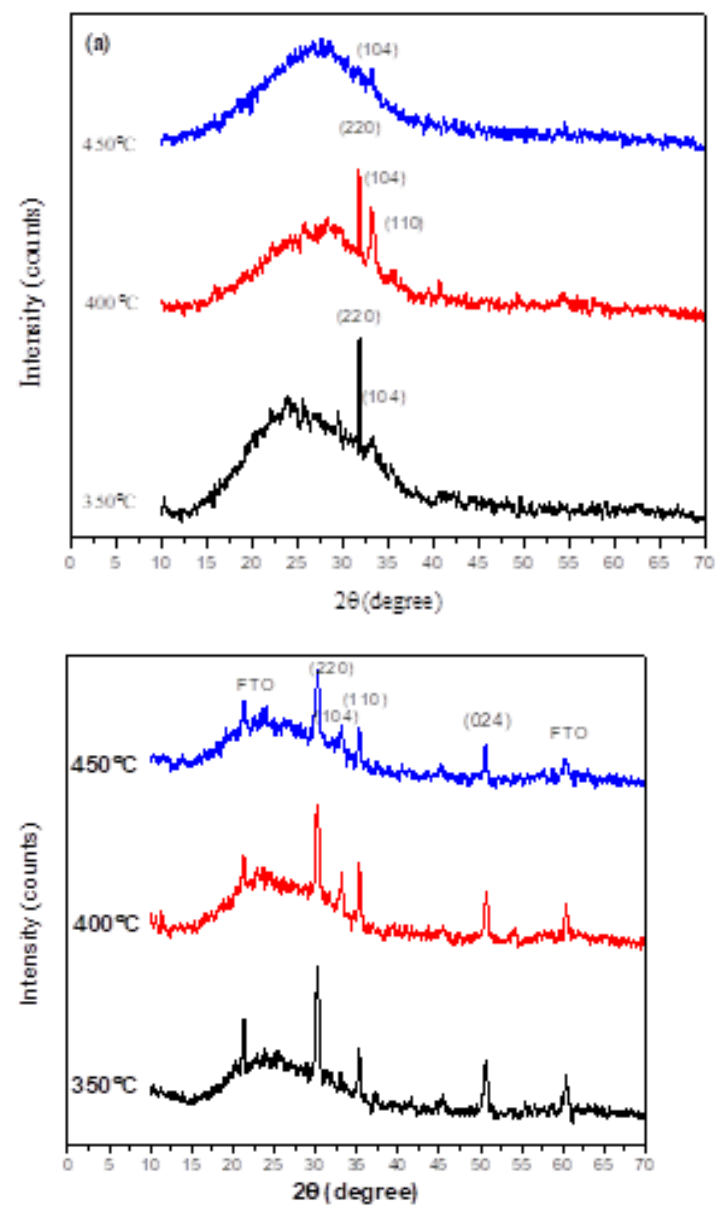

Fig. 1. XRD spectra of $\mathrm{Fe}_{2} \mathrm{O}_{3}$ films deposited on (a) glass and (b)FTO coated glass substrates at different substrate temperatures.

Table 1. Peak list of the iron oxide films on glass and FTO coated conducting glass substrates

\begin{tabular}{|c|c|c|c|c|}
\hline \multirow{2}{*}{$\begin{array}{l}\text { Temp } \\
\left({ }^{\circ} \mathrm{C}\right)\end{array}$} & \multicolumn{2}{|c|}{$\begin{array}{l}\text { Planes } \\
(\mathrm{h} \mathrm{k} \mathrm{1)}\end{array}$} & \multicolumn{2}{|l|}{ Phase } \\
\hline & Glass & FTO & Glass & FTO \\
\hline \multirow{4}{*}{350} & 220 & 220 & Maghamite & Maghamite \\
\hline & 104 & 104 & Hematite & Hematite \\
\hline & & 110 & & Hematite \\
\hline & & 024 & & Hematite \\
\hline \multirow{4}{*}{400} & 220 & 220 & Maghamite & Maghamite \\
\hline & 104 & 104 & Hematite & Hematite \\
\hline & 110 & 110 & Hematite & Hematite \\
\hline & & 024 & & Hematite \\
\hline \multirow{4}{*}{450} & 116 & 220 & Hematite & Maghamite \\
\hline & & 104 & & Hematite \\
\hline & & 110 & & Hematite \\
\hline & & 024 & & Hematite \\
\hline
\end{tabular}

The films grown on glass substrates are found to be microcrystalline in nature shown in Fig.1(a) . A sharp peak is observed at $2 \theta=31.66^{\circ}$ for the film at substrate temperature $350^{\circ} \mathrm{C}$. For $400^{\circ} \mathrm{C}$ substrate temperature, three peaks are seen at $2 \Theta=31.72^{\circ}, 33.16^{\circ}, 35.6^{\circ}$ which indicate the improvement of the crystalline nature of the films. The reflections are observed for the (220), (104), and (113) 
planes accordingly. All the peaks identified here are due to hematite $\mathrm{Fe}_{2} \mathrm{O}_{3}$ phase ${ }^{1}$. A broad hump is seen for the film at substrate temperature $450^{\circ} \mathrm{C}$. One peak is identified here. The thin film may have lost its crystalline nature in this case. Fig. 1(b) represents $\mathrm{Fe}_{2} \mathrm{O}_{3}$ films on FTO coated conducting glass substrates. All the films are found polycrystalline in nature. The reflections are observed for (220), (104), (110), (024) planes indicating the rhombohedral structure $^{2}$. The peaks at $2 \Theta=21.35^{\circ}, 60.34^{\circ}$ in Fig.(b) are seen due to $\mathrm{FTO}^{9}$.With increasing substrate temperature, the intensities of the films are found to be decreasing. Decrease in intensity can be caused due to the deterioration of crystalline quality. In both figures, the diffraction peaks show the presence of crystalline $\alpha-\mathrm{Fe}_{2} \mathrm{O}_{3}$ hematite phase with the rhombohedral structure shown in Table $1^{9,13}$. One peak at $2 \theta=31.70$ has been identified due to 220 plane of maghemite ${ }^{15,16}$.The values of $a$ and $c$ and $c / a$ ratio are given in Table 2. The lattice constants are comparable to the standard values of $a=5.0353$ and $c=13.7495 A$ of $\alpha$ $\mathrm{Fe}_{2} \mathrm{O}_{3}$ hematite phase ${ }^{9}$.

Table. 2. Lattice constants of the films at different substrate temperatures $\left(350^{\circ} \mathrm{C}, 400^{\circ} \mathrm{C}\right.$, and $450^{\circ} \mathrm{C}$ )

\begin{tabular}{|l|l|l|l|}
\hline \multirow{2}{*}{$\begin{array}{l}\text { Substrate } \\
\text { Temp. }\end{array}$} & \multicolumn{3}{l}{ Lattice constants } \\
\cline { 2 - 4 } & $a$ & $c$ & $c / \mathrm{a}$ \\
\hline $350 \circ \mathrm{C}$ & 5.06 & 13.69 & 2.70 \\
\hline $400 \circ \mathrm{C}$ & 5.06 & 13.58 & 2.67 \\
\hline $450 \circ \mathrm{C}$ & 5.08 & 13.74 & 2.70 \\
\hline
\end{tabular}

Crystallite size has been calculated from the stronger peaks of (110) from each XRD patterns using Scherrer's formula for the films on FTO coated conducting glass substrates shown in Fig. 2.

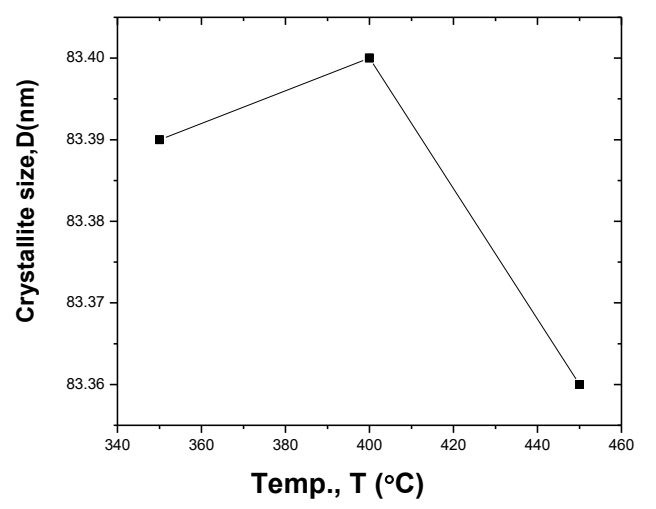

Fig. 2. Variation of crystallite size with temperature for the film deposited on FTO coated conducting glass substrate.

\section{Morphological characterization}

Fig. 3 shows the AFM imagesof the $\mathrm{Fe}_{2} \mathrm{O}_{3}$ films on glass and FTO coated conducting glass substrates grown at substrate temperature $400^{\circ} \mathrm{C}$. The films were annealed at $300^{\circ} \mathrm{C}$ for $1 \mathrm{hr}$. The images shows clearly the difference between the surface morphology and roughness of the films on glass and FTO coated conducting glass substrates. Fig.3(a,b) shows the roughness images of the films on glass substrates before and after annealing.The roughness images for the films on FTO coated conducting glass substrates are shown in Fig.3(c,d) before and after annealing. The roughness values for the films on glass and FTO coated conducting glass substrates are summarized in Table 2.

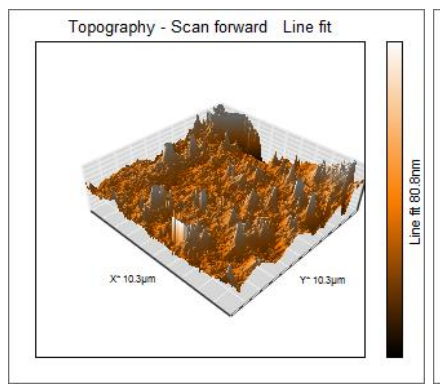

(a)

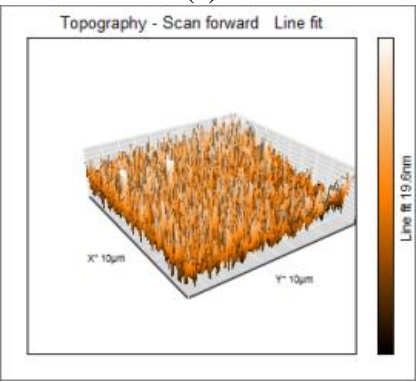

(c)

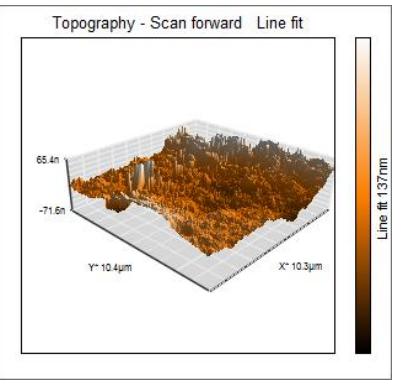

(b)

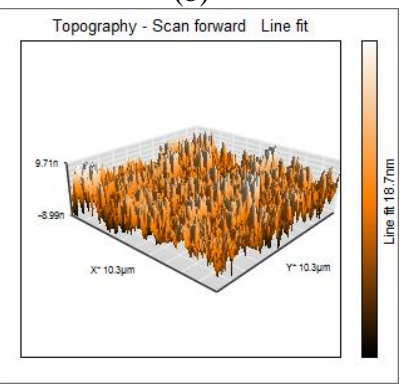

(d)
Fig. 3. Roughness images of the films deposited at $400^{\circ} \mathrm{C}$ substrate temperatureon glass (a) before (b) after annealing .Roughness images of the films at $400^{\circ} \mathrm{C}$ substrate temperature on FTO coated conductingglass substrates (c)before (d) after annealing .

Table 2. Roughness values of the films as measured from the AFM images

\begin{tabular}{|c|c|c|c|c|c|}
\hline \multirow{2}{*}{$\begin{array}{l}\text { Deposition } \\
\text { Temp. }\end{array}$} & \multirow[b]{2}{*}{ Substrate } & \multicolumn{2}{|c|}{$\begin{array}{l}\text { Roughness average, } \\
\mathrm{Sa}(\mathrm{nm})\end{array}$} & \multicolumn{2}{|c|}{$\begin{array}{l}\text { RMS roughness, Sc } \\
(\mathrm{nm})\end{array}$} \\
\hline & & $\begin{array}{l}\text { As } \\
\text { deposited }\end{array}$ & $\begin{array}{l}\text { Annealed } \\
\left(300^{\circ} \mathrm{C}\right. \\
\text { for } 1 \mathrm{hr})\end{array}$ & $\begin{array}{l}\text { As } \\
\text { deposited }\end{array}$ & $\begin{array}{l}\text { Annealed } \\
\left(300^{\circ} \mathrm{C}\right. \\
\text { for } 1 \mathrm{hr})\end{array}$ \\
\hline \multirow{2}{*}{$400 \circ \mathrm{C}$} & Glass & 7.54 & 16.38 & 12.82 & 22.70 \\
\hline & FTO & 3.11 & 2.34 & 4.31 & 3.00 \\
\hline
\end{tabular}

From the images and the table it is observed that (i) the film adhesion is better on FTO coated conducting glass substrate than the films on glass substrate (ii) the deposition temperature increases the mobility of ad-atoms provides better arrangement of atoms. Also the transparent conduction surface plays an important role for the good crystalline nature of the films because of the nucleation formation. On the other hand the films on the glass substrates are inhomogeneous which may be due to the presence of voids. 
As a consequence the films on glass are found to be $\operatorname{rough}^{14,17}$.

\section{Optical Characterizations}

Fig. 4 and Fig. 5 show the transmission spectra of the films on glass substrates in the wavelength range $200-1200 \mathrm{~nm}$. The substrates temperatures were at $350^{\circ} \mathrm{C}, 400^{\circ} \mathrm{C}$, and $450^{\circ} \mathrm{C}$ and the films wer eannealed at $300^{\circ} \mathrm{C}$ for $1 \mathrm{hr}$. Fig. 4 (a) and Fig. 4 (b) represent the transmission spectra of $\mathrm{Fe}_{2} \mathrm{O}_{3}$ thin films on glass substrates before and after annealing. The transmission spectra of $\mathrm{Fe}_{2} \mathrm{O}_{3}$ films on FTO coated conducting glass substrates before and after annealing are shown in Fig. 5 (a) and Fig. 5 (b). In both cases the transmittance is observed to be about $40-80 \%$ in the wavelength range $500-1100 \mathrm{~nm}$.
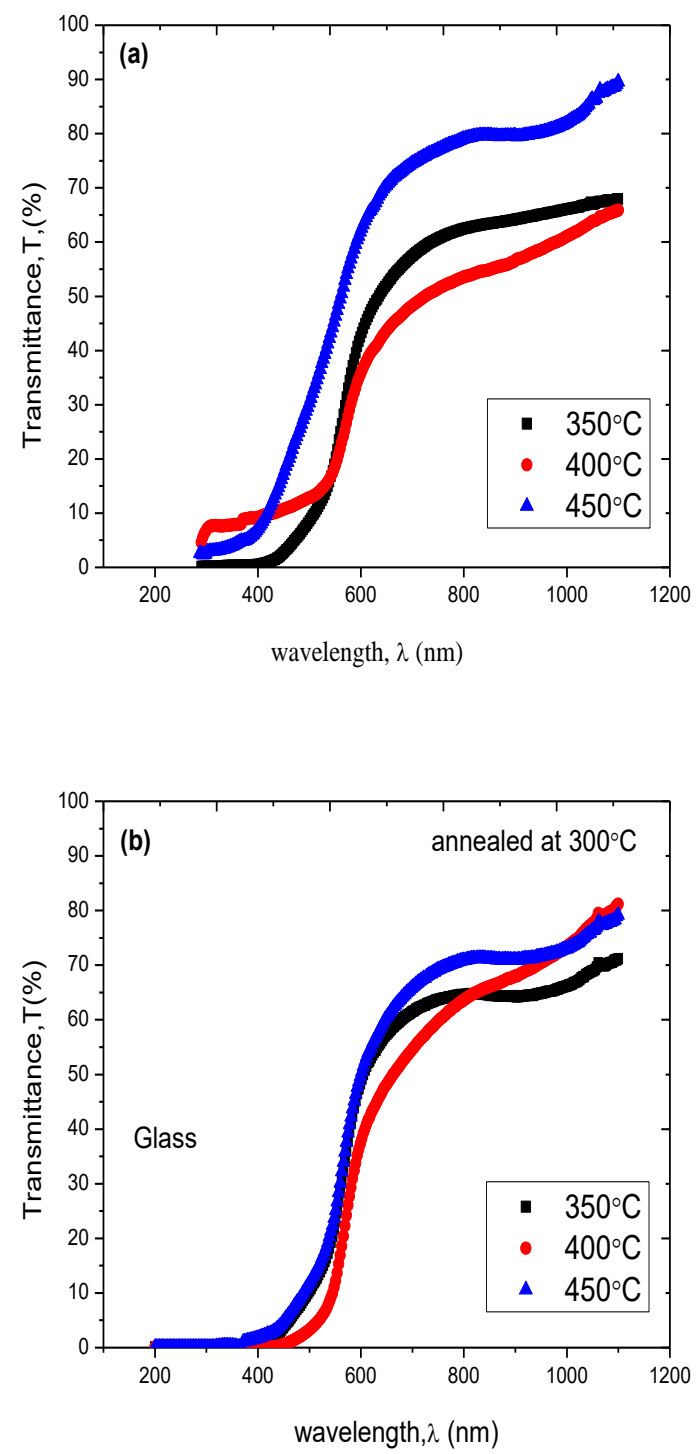

Fig. 4. Transmission spectra of $\mathrm{Fe}_{2} \mathrm{O}_{3}$ films on glass substrates (a) before and (b) after annealing at $300^{\circ} \mathrm{C}$ for $1 \mathrm{hr}$.
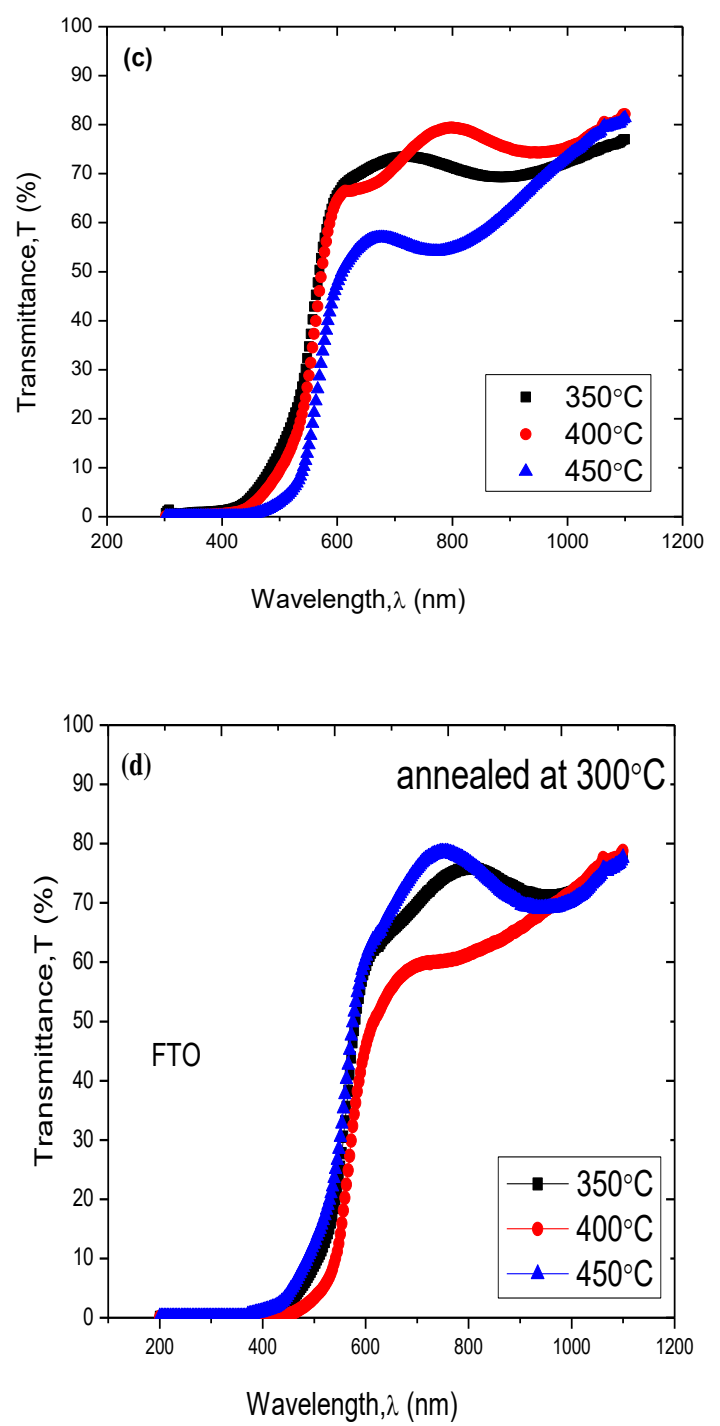

Fig. 5. Transmission spectra of $\mathrm{Fe}_{2} \mathrm{O}_{3}$ films on FTO coated conducting glass substrates (a) before and (b) after annealing at $300^{\circ} \mathrm{C}$ for 1 hour.

The transmission spectra of the films can be affected due to (i) roughness of the surface (ii) optical inhomogeneity in the direction normal to the film surface.The broad cut off towards short wavelengths indicates the onset of intrinsic inter-band absorption in the films. The high transparency in the visible region and above results in wide band gap of the films ${ }^{18}$. No significant changes in the transmittance curves have been observed for the films on both glass and FTO coated conducting glass substrates. When annealed at $300^{\circ} \mathrm{C}$ for $1 \mathrm{hr}$, the transmission curves have become smooth. High transmittance of the films in the wavelength range 500-1100 nm suggests that the film can be used as a window or buffer layer in CIGS solar cells.

Fig. 6 and Fig. 7 show the absorptions pectra of the films in the wavelength range $300-1200 \mathrm{~nm}$ on glass and FTO coated conducting glass substrates. The substrates were 
kept at $350^{\circ} \mathrm{C}, 400^{\circ} \mathrm{C}$, and $450^{\circ} \mathrm{C}$ and the annealing temperature was maintained at $300^{\circ} \mathrm{C}$ for $1 \mathrm{hr}$.
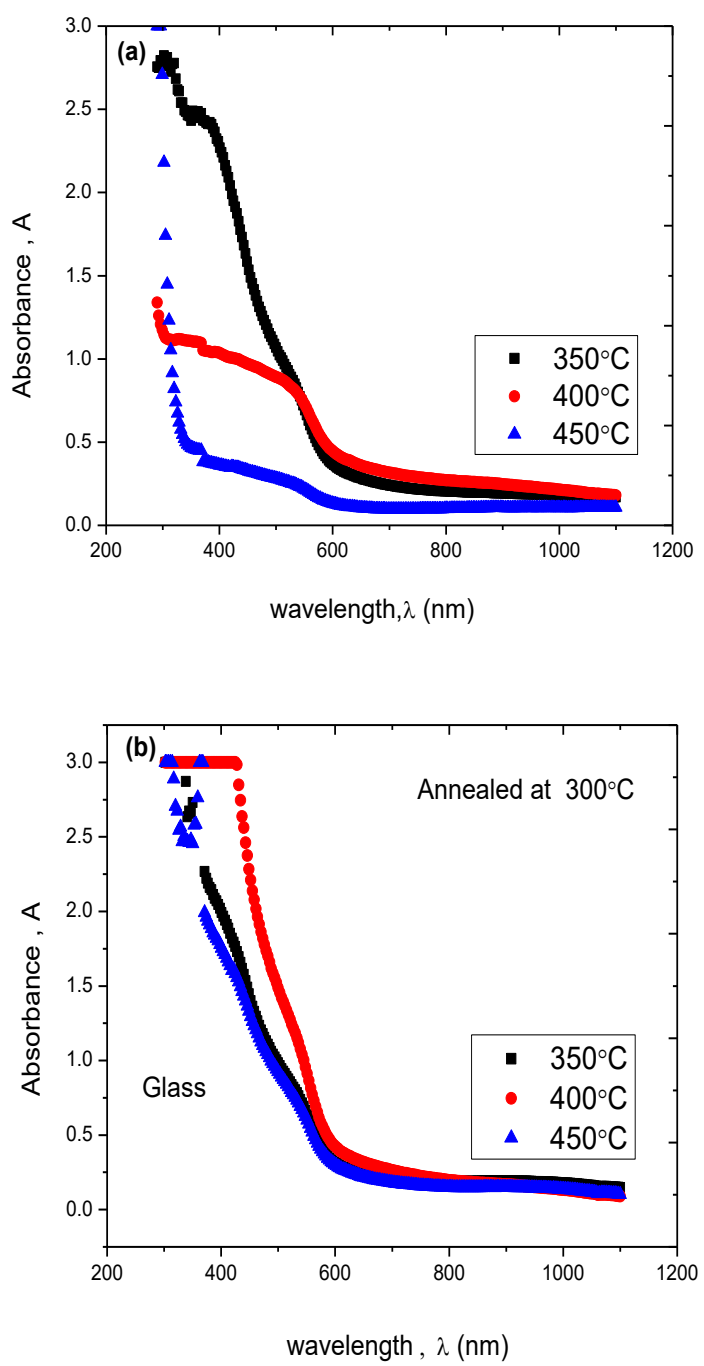

Fig. 6. Absorption spectra of $\mathrm{Fe}_{2} \mathrm{O}_{3}$ films on glass (a) before and after annealing at $300^{\circ} \mathrm{C}$ for $1 \mathrm{hr}$.

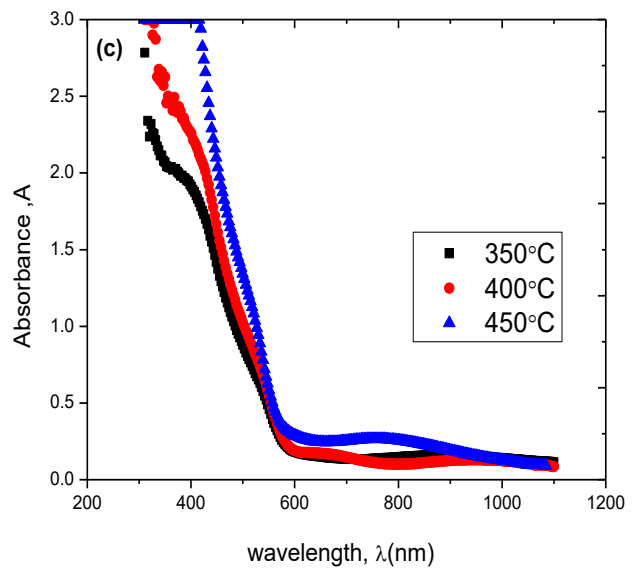

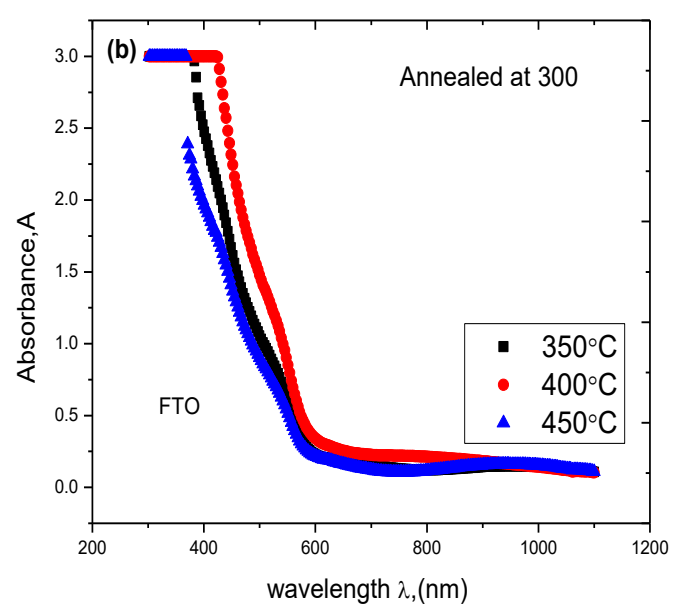

Fig. 7. Absorption spectra of $\mathrm{Fe}_{2} \mathrm{O}_{3}$ films on FTO coated conducting substrates (c) before and (d) after annealing at $300^{\circ} \mathrm{C}$ for $1 \mathrm{hr}$.

A sharp decrease up to $600 \mathrm{~nm}$ of the absorbance curves has been observed and the curves became almost stable above $700 \mathrm{~nm}$. The absorption about the band edge is sharp revealing that the $\mathrm{Fe}_{2} \mathrm{O}_{3}$ film has a direct band gap ${ }^{18}$. The crystalline quality has been found to be improved upon annealing. No significant change has been observed in the absorption spectra of the films grown on glass and FTO coated conducting glass substrates.

Optical band gap $\left(E_{g}\right)$ of $\mathrm{Fe}_{2} \mathrm{O}_{3}$ thin films both on glass and FTO coated conducting glass substrates are determined by plotting $(\alpha h v)^{2}$ as a function of band gap energy, $h v$ followed by the Lambert law, $\alpha$ is the coefficient of absorption $^{19}$ defined by the expression:

$\alpha=\frac{A_{o}\left(h v-E_{g}\right)^{n}}{h v}$

wher en $=0.5$ for direct band gap material or 2 for indirect band gap material or $2, h v$ is the photon energy, $E_{g}$ is the band gap energy, $A_{o}$ is a constant related to the effective masses associated with the bands. Since $\mathrm{Fe}_{2} \mathrm{O}_{3}$ is a direct band gap material, therefore taking , $\mathrm{n}=0.5$,equation (1) takes the form

$(\alpha h v)^{2}=A_{o}^{2}\left(h v-E_{g}\right)$

Fig. 8 and Fig. 9 show the plots $(\alpha h v)^{2}$ as a function of band gap energy, $h v$ for the films on glass and on FTO coated conducting glass substrates. From these figures the extrapolation of the linear region of the curves on the energy axis $h v$ has been used to find out the direct band gap $E_{g}$ of $\mathrm{Fe}_{2} \mathrm{O}_{3}$ thin films.Fig. 8 (a,b) represents $\mathrm{Fe}_{2} \mathrm{O}_{3}$ films on glass before and after annealing whereas Fig. 9 (c, d) shows $\mathrm{Fe}_{2} \mathrm{O}_{3}$ films on FTO coated conducting glass substrates before and after annealing. The direct band gap values of $\mathrm{Fe}_{2} \mathrm{O}_{3}$ thin films on glass and FTO coated conducting glass substrates as obtained from the figures are summarized in Table 3. 

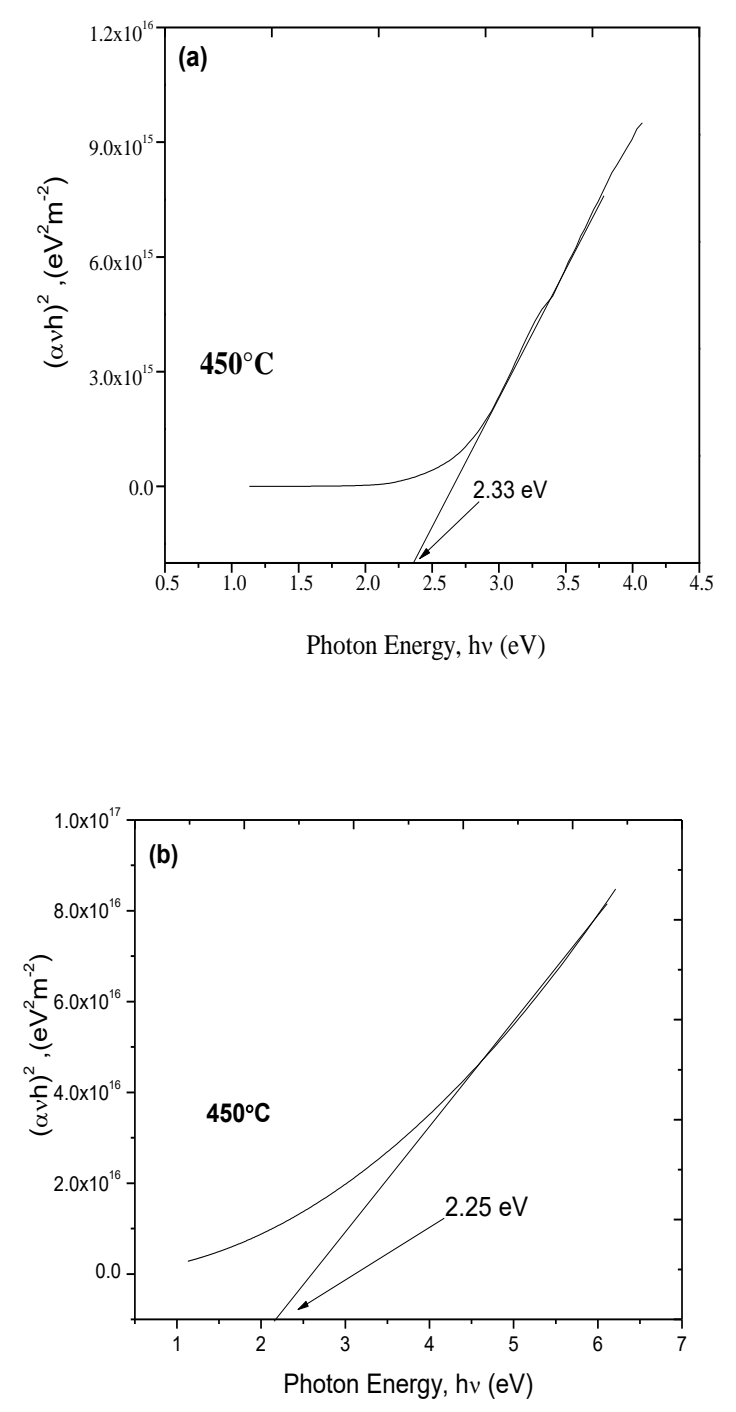

Fig. 8. Plots of $(\alpha h v)^{2}$ vs. $h v$ for $\mathrm{Fe}_{2} \mathrm{O}_{3}$ thin films on glass substrates at substrate temperature $450^{\circ} \mathrm{C}$ (a) before (b) after annealing at $300^{\circ} \mathrm{C}$ for $1 \mathrm{hr}$.

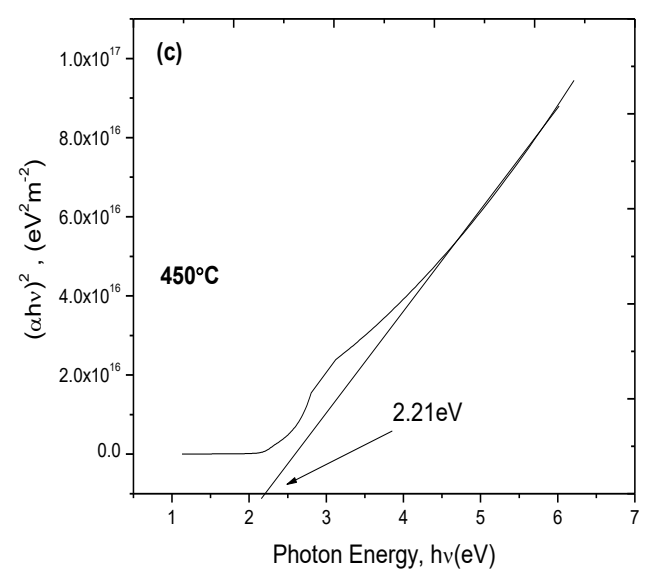

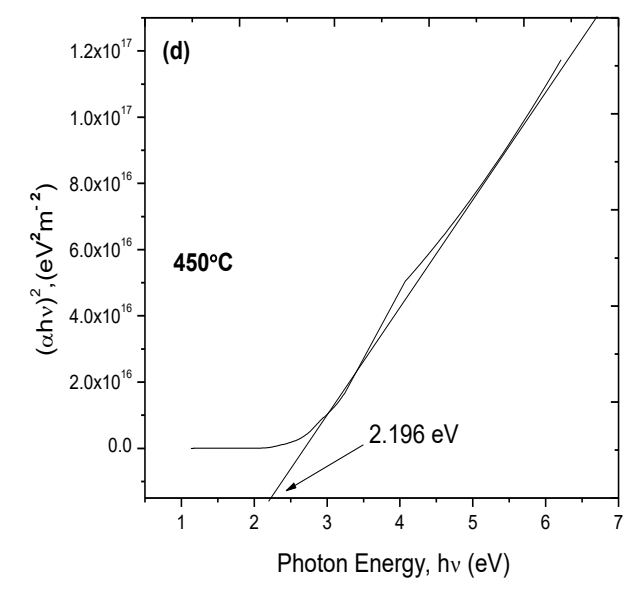

Fig. 9. Plots of $(\alpha h v)^{2}$ vs. hv for $\mathrm{Fe}_{2} \mathrm{O}_{3}$ thin films on FTO coated conducting substrates at substrate temperature $450^{\circ} \mathrm{C}$ (c) before (d) after annealing at $300^{\circ} \mathrm{C}$ for $1 \mathrm{hr}$.

Table 3. Direct band gap values of $\mathrm{Fe}_{2} \mathrm{O}_{3}$ thin films on glass and FTO coated conducting glass substrates before and after annealing

\begin{tabular}{|l|l|l|l|l|}
\hline \multirow{2}{*}{$\begin{array}{l}\text { Substrate } \\
\text { Type }\end{array}$} & Temp. & \multicolumn{3}{|l|}{ Band Gap, $E_{g}(\mathrm{eV})$} \\
\cline { 3 - 4 } & & As deposited & Annealed & $\begin{array}{l}\text { Standard } \\
\text { Values }\end{array}$ \\
\hline \multirow{4}{*}{ Glass } & $350^{\circ} \mathrm{C}$ & 2.37 & 2.30 & \\
\cline { 2 - 4 } & $400{ }^{\circ} \mathrm{C}$ & 2.125 & 2.10 & \\
\cline { 2 - 4 } & $450{ }^{\circ} \mathrm{C}$ & 2.33 & 2.25 & \multirow{4}{*}{$2.2-3.3$} \\
\hline \multirow{4}{*}{ FTO } & $350^{\circ} \mathrm{C}$ & 2.24 & 2.20 & \\
\cline { 2 - 4 } & $400{ }^{\circ} \mathrm{C}$ & 2.25 & 2.13 & \\
\cline { 2 - 4 } & $450{ }^{\circ} \mathrm{C}$ & 2.21 & 2.20 & \\
\hline
\end{tabular}

Table 3 shows that the band gap energy values of the annealed samples are less than the values obtained for the as-deposited films. Band gap energy values $E_{g}$ have been reported between 2.2 and $3.3 \mathrm{eV}$ for single crystal $\mathrm{Fe}_{2} \mathrm{O}_{3}$ ${ }^{10,20}$.The band gap values $\mathrm{E}_{\mathrm{g}}$ values in our work are found to be between 2.10 and $2.37 \mathrm{eV}$, the results obtained are in good agreement with those obtained for single crystal $\mathrm{Fe}_{2} \mathrm{O}_{3}$. It can be inferred that (i) the band gap energy values are affected by the substrate temperature and film thickness (ii) the annealing temperature can reduce the energy gap of the film ${ }^{21}$. (iii) There may be other phases like Maghemite, $\mathrm{Fe}_{3} \mathrm{O}_{4}$ etc. present in the films (iv) The large value of the band gap energy may be due to quantum size effect (v) low value of band gap is due to disorder at the grain boundary ${ }^{21}$.

\section{Conclusion}

$\mathrm{Fe}_{2} \mathrm{O}_{3}$ thin films have been synthesized successfully by spray pyrolysis technique on glass and FTO coated conducting glass substrates The substrates were preheated at different substrate temperatures $\left(350^{\circ} \mathrm{C}, 400^{\circ} \mathrm{C}\right.$, and $450^{\circ} \mathrm{C}$ ). The substrate type and the temperature effects on the structural, morphological, and optical properties of the films were analysed. XRD pictures reveal that the films on FTO coated conducting glass substrate are more crystalline than the films grown on glass substrate. Most 
of the diffraction peaks are identified as crystalline $\alpha$ $\mathrm{Fe}_{2} \mathrm{O}_{3}$ hematite phase. Moreover, using FTO coated conducting glass substrate, polycrystalline films were possible to grow even at temperature $350^{\circ} \mathrm{C}$ and the low deposition time. Because of the good adhesion of the films on the FTO coated conducting glass substrate before and after annealing as can be seen from the AFM images, the films were found crystalline and smooth. The structure of $\mathrm{Fe}_{2} \mathrm{O}_{3}$ thin films on glass substrates remained amorphous with $\alpha-\mathrm{Fe}_{2} \mathrm{O}_{3}$ phases present. At low substrate temperature $350^{\circ} \mathrm{C}$,poor adhesion of the films to the substrate was observed but at higher temperatures agglomeration of particles as well as voids were observed in the AFM studies. As a result the surface of the films became rough $^{10,22}$. The high transmittance and the low absorbance of the crystalline $\mathrm{Fe}_{2} \mathrm{O}_{3}$ films on FTO coated conducting glass substrates in the wavelength range $(500-1100 \mathrm{~nm})$ have been observed that can be used as a window layer in the CIGS cell .A small band gap of about 2.10-2.37 eVmakes iron oxide films to be used as photoelectrodes. Also because of the small band gap values, $\mathrm{Fe}_{2} \mathrm{O}_{3}$ films can absorb a significant amount of sunlight and can be used as a material for PEC cells ${ }^{12}$. The amorphous $\mathrm{Fe}_{2} \mathrm{O}_{3}$ thin films on glass substrates with high transmittance can be used to make thin film solar filters ${ }^{14}$.

In conclusion, it can be inferred that the structural, morphological, and optical properties of $\mathrm{Fe}_{2} \mathrm{O}_{3}$ thin films are influenced by the temperature and the substrate type. Our studies suggest that FTO coated conducting glass substrates can be a better choice as a substrate for the deposition of $\mathrm{Fe}_{2} \mathrm{O}_{3}$ thin films.

\section{Acknowledgement}

The work was financially supported by the International Science Program (ISP), Uppsala University, Sweden.

\section{References}

1. Gesheva K, T.Ivanova, G.Bodurov, I.M.Szilágyi, N. Justh, O.Kéri, S.Boyadjiev,D.Nagy and M. Aleksandrova, 2016. Technologies for deposition of transition metal oxide thin films: application as functional layers in "Smart windows" and photocatalytic systems. J.Phys., 682, 012011.

2. Kung H.H, 1989.Trans.Met. Oxid.: Surf. Chem. Cata., Elsevier. 45,

3. Chodankar N.R, D. P. Dubal, G. S.Gund\&C. D. Lokhande, 2015. Flexible all-solid-state $\mathrm{MnO}_{2}$ thinfilms based symmetricsupercapacitors, Electrochim. Act., 165, 338-347.

4. Ying T, L.Zongyu, X.Rong, H. Liping,2016.An efficient supercapacitor of three-dimensional $\mathrm{MnO}_{2}$ film prepared by chemical bath method, J.Allo. Comp., 671, 312-317.

5. Wei C, P.S.Lee, Z.Xu,2014. A comparison of carbon supports in $\mathrm{MnO}_{2} / \mathrm{C}$ supercapacitors. RSC Adv., 4(59), 31416-31423.

6. TominagaJ,The application of silver oxide thin films to plasmon photonic devices, 2003.J.Phys. Cond. Matt., 15(25), R1101.
7. Shuxi Z,R.Carl-Gusta,E. Wäckelgård, Optical constants of sputtered $\mathrm{Ni} / \mathrm{NiO}$ solar absorber film depth profiled characterization, 2004.Sol.Ener.Mat.Sol.Cell., 84(1-4), 193203.

8. Batzill M, U. Diebold, 2005.The surface and materials science of tin oxide.Prog.Surf.Sci., 79(2-4),47-154.

9. CornellR M, U.Schwertman, 2003. The Iron Oxid., sec. ed.,wiley-VCH, 11.

10. Aki A A, 2004. Optical properties of crystalline and noncrystalline iron oxide thin films deposited by spray pyrolysis, App. Surf. Sci. 233, 307-319.

11. Salam A Y, 2015. Effect of heat treatment on the optical and morphological properties of iron oxide thin films prepared by spray pyrolysis, Mat. Sci. Ind. Jour., 12(3), 069-075.

12. Batin M N, V.Popescu,2012. The influence of deposition time on optical properties of iron oxide films grown on glass substrate by Chemical Bath Deposition, Optoelec. Adv. Mat.Rap. Commun., 6(7-8), 727-729.

13. Desai J D, H.M. Pathan, et.al, 2006. Preparation and characterization of iron oxide thin films by spray pyrolysis using methanolic and ethanolic solutions, App. Surf. Sci., 252, 2251-2258.

14. Garcia-Lobato M A, A. Hernandez-V, H.M. Hdz-Garcia, A.I. Martinez, and M.I. Pech-Canul, 2010. $\mathrm{Fe}_{2} \mathrm{O}_{3}$ thin films prepared by Ultrasonic Spray Pyrolysis, Mat. Sci. Foru., 644, 105-108.

15. JCPDF File Nos.39-1058, 33-0664 and 39-13.

16. Hongtao C, L.Yan, R.Wanzhong, 2013. Structure switch between $\alpha-\mathrm{Fe}_{2} \mathrm{O}_{3}, \gamma-\mathrm{Fe}_{2} \mathrm{O}_{3}$ and $\mathrm{Fe}_{3} \mathrm{O}_{4}$ during large scale and low temperature sol-gel synthesis of nearly monodispersed iron oxide nanoparticles, Adv. Pow. Tech., 24, 93-97.

17. Houseman LH, E.M. Barbara, 1968. The influence of substrate temperature on the sticking coefficient of Zinc on glass, US Army, Nucl. Def. Lab., 1-26.

18. Zhang N, J.Jian Sun, H. Gong, 2019. Transparent p-Type Semiconductors: Copper-Based Oxides and Oxychalcogenides , Coatings,1-27.

19. Lehraki N, M.Saida, S. Abed, N. Attaf, A. Attaf,M.Poulain, 2012.ZnO thin films deposition by spray pyrolysis: Influence of precursor solution properties, Current App.Phys., 1-5.

20. Zhenguo J, L.Kun, C.L.Y.Yang, F.Ruixin, Y.Zhizhen, 2003. Structural, optical and electrical properties of $\mathrm{ZnO}$ thin films prepared by reactive deposition, J.Crys. Growth, 253(1-4), 246-251.

21. Romero R, F. Martin, J.R. Ramos-Barrado, D.Leinen,2010. Synthesis and characterization of nanostructured nickel oxide thin films prepared with chemical spray pyrolysis, Thin Sol.Fil., 518,4499-4502.

22. Mekhnache M, A. Drici, L. Saad Hamideche, H. Benzarouk, A. Amara, L. Cattin, J.C. Bernede, M. Guerioune, 2011. Properties of $\mathrm{ZnO}$ thin films deposited on (glass, ITO and ZnO:Al) substrates, Superlatt.Microstruc., 49, 510-518. 
